\title{
Spiritual vulnerability through demonization in curses? A critical reassessment
}

\author{
Cheong Weng Kit,106
}

\begin{abstract}
This paper examines the Pentecostal/charismatic concerns of spiritual vulnerability of Christians through demonisation in curses. It will studies popular writes such as Derek Prince and Rebecca Brown and academic authors such as Charles Kraft and Ed Murphy to assess the accuracy of such views in comparison to the biblical data on curse to propose a more robust and sound theological, ministerial and misssiological understanding and praxis for how Christians may engage with curses.
\end{abstract}

\section{Introduction}

Among all Christian denominations, the topic of spiritual warfare is most commonly found among Pentecostals and charismatics due to its emphatic theological and ministerial stress of the power of the Holy Spirit and its traditional engagement with spiritual warfare in its history (Anderson 2004:231-234). Such engagements have included deliverance ministries (i.e., demon exorcism) (Reddin 1996), territorial spirits (i.e., praying against spirits that rule over certain geographical sites) (Dawson 1989), curses (Prince 2008) and engaging objects and places that are demonized (Kraft 1995).

Because the subject of spiritual warfare in Pentecostal/charismatic Christianity (henceforth $\mathrm{P} / \mathrm{C}$ ) is broad, this paper will focus on the $\mathrm{P} / \mathrm{C}$ concern of spiritual vulnerability of Christians through demonisation in curses. It will first examine popular writers such as Derek Prince and

106 Paper submission to Jurnal Teologi Amreta on 30 June 2017. With the submission of this paper, I affirm that this is an original contribution and that I have not submitted this to any other journal nor is this published anywhere. 
Rebecca Brown and academic authors such as Charles Kraft, Ed Murphy and Timothy Warner; the latter are important because they have provided many popular writers great theological and ministerial and misssiological support for the specific ways in which they do spiritual warfare in their ministries. In this paper, $\mathrm{P} / \mathrm{C}$ will be used as a general catchall category to refer to the broad movement, it will be distinguished from "charismatics", which refer to the those who are not of the classical first wave of Pentecostalism (Anderson 2004:9-15).

The paper will particularly intersect with missiological views of the subject due to the more robust theological, sociological and missiological aspects that are generally integrated there. It will examine some supporting and contrasting views of understanding the phenomenon of curses through a critical reading of key but select biblical data. It will conclude with some focused pastoral and missiological implications for ministry based on an overall assessment of this examination with an eye for sound biblical understanding and practices of spiritual warfare in this area.

\section{Are Christians spiritually vulnerable through curses?}

Curses through generational sins

The notion that Christians may be vulnerable to curses (e.g., hateful spells) uttered by Satanists, witch doctors or pagans, and that they can become afflicted or demonised are common in popular charismatic teachings such as Brown and Yoder (1995) or Prince (2008) and even among academic authors such as Kraft (1995) and Murphy (2003). That the topic of spiritual warfare and curses is popular is demonstrated in the wide availability of such books that have been translated into Chinese, Indonesian and so on. According to such authors, there are at least three ways that Christians can be vulnerable to curses: (1) generational sins, where an ancestor that was cursed, or involved in witchcraft or some demonic activity becomes an ancestral channel that allows this evil to flow through one's bloodline to 
succeeding generations (Brown and Yoder 2008, Prince 1995) (2) be directly cursed by a satanist, witch doctor or pagan or (3) come into contact through a cursed object or place (Kraft 1995).

According to the non P/C theologian Fred Dickason (1987:211), "ancestral involvement [is] the chief cause of demonization [in] over 95 percent of more than 400 persons ... because of their ancestors' involvement in occult and demonic activities". Etiologically, generational sins may occur when ancestral sins or occult activities give demons special rights to attach to the descendants (Warner 1991:106-109) or when parents dedicate their offspring to a spirit or god or when they seek spirit power to become pregnant, the child will often be "demonized from the moment of conception" (Kraft 1992:262). Ed Murphy (2003:437) states:

generational $\sin$ is sin judgment which moves through the family line. It is caused by various other names such as transference, inheritance, or familial sin. In some cases, demons seem to become identified with a family line. This then leads to demonic inheritance, and potential generational demonization.

Evangelical anthropologist Robert Priest states that this "may be associated with a family curse or may simply occur naturally. A child, for example, may acquire a demon from his parents, perhaps at the very point of conception" (Priest et al 1995:18).

Murphy (2003:xiv) also believes that demons can also "enter the bodies and lives of abused children, especially those who have experienced SRA [Satanic ritual abuse], and of practicing New Agers". So serious is this possible avenue of demonisation that to "free people spiritually from satanic deception in ancestral matters, we have to deal with the family demons that ancestral practices invite in" (Kraft 2002:307). In such situations, Kraft notes that he has had to "take authority over the father's bloodline and then the mother's to break the power of and cancel all curses, dedications ... and any other satanic influence that may have been introduced into the person's inheritance" (1992:151; cf. also Wimber 1987:227). 
According to Murphy, sometimes generational demonic transference also occurs since adoptive parents seldom know the full ancestry of their adopted or foster children (1992:437-438, 472-473). If it is discovered there is such a case, parents are encouraged to "take [them] through deliverance" (Murphy 1992:438). Wimber (1987:117) cautions that "Christians can also be demonized if inherited demons ... are not cast out of their lives".

Biblical support for the existence of generational curses or sins frequently cite Exodus 20:5: "You shall not bow down to them or worship them; for I, the Lord your God, am a jealous God, punishing the children for the sin of the parents to the third and fourth generation of those who hate me".107

In some Pentecostal circles, Ezekiel 18:2 and Jeremiah 31:29 have also been used to cite biblical support for generational sins. However, Ex 20:5 will be examined in detail as it is the most cited foundational text for this argument.

A first glance at Ex 20:5 reveals that strong biblical support of the efficacy of a curse coursing through generational sins does exist. However, a proper reading of verse 5 must also include reading it in its full context. When we do so, we observe that verse 6 states: "but showing love to a thousand generations of those who love me and keep my commandments" [italics mine]. A clear conclusion of reading verses 5 and 6 together is that generational sins still apply only until a certain point. The sin or curse is broken for those who repent and turn to God - that is, those "who love me and keep my commandments". However, in any cursory survey of many lay or popular writings on spiritual warfare and generational sins and curses, verse 6 is often omitted, as evidenced by writers such as Derek Prince (2008:19), Rebecca Brown (Brown and Yoder 1995:25), and others (Murphy 2003:252).

In addition to the truncated reading and interpretation of Ex 20:5, such writers expand the list of curses that Christians are vulnerable to. For instance, Prince (2008:46-48) lists the following as curses: disturbances to

107 All references are from the New International Version unless otherwise indicated. 
the soul and nerve, chronic disease, abortion, family conflicts, endemic poverty, tendency towards ill-fortune, untimely disaster or death in the family. They are all cited by Prince from his personal ministry experience, with none having any Scriptural support. For Brown and Yoder (1995:42-44), they cite various Old Testament passages such as Deut 30:19, Leviticus 26:39-42 to assert that the sins of ancestors are the same as a curse.

A further reading of Ex 20:5 shows that there is no mention of demons at all. David Powlison (1995:127) states that this verse does not hint at any generational passing of demons but simply that "sin will be judged". New Testament scholar Clinton Arnold concurs, noting that Ex 20:5 "speak of guilt and consequential punishment, not about familial spirits passed on the third and fourth generations" (1997:119). If demons are absent in Ex 20:5, then it "does not mean that demons are always passed from one generation to another [but] in some cases they may be people who have been sinned against sexually [or] children of alcoholics [where] in many instances demonic influence contributes to their problem" (Wimber 1987:119). In other words, "it is typical for sinful patterns in a family to repeat themselves in succeeding generations [1 $\mathrm{Kg} 15: 3,26,34 ; 22: 52]$ (Arnold 1997:124). Reddin (1999:202) rightly states that the

only family totally affected by $\sin \ldots$ is the human family. By one man sin entered the world (Rom 5:12). Every baby is conceived with this sinful nature inherent (Psalm 51:5), but children are not held accountable until they personally commit sin ... The only bloodline that is involved with the sinful nature is that from Adam (Rom 5:17-19) and Eve (1 Tim 2:14). [bold in original]

However, it is through the writings and the simplistic exegesis of Scripture by popular authors such as Prince, Brown and Yoder as well as academics such as Kraft and Murphy that fear and insecurity are generated among readers, particularly Christians. Even though they may have already put their trust in Christ, keep his commandment and thus break any such generational sins or curse, their interpretations teaches believers to hold on to a needless fear of constant vulnerability. Perhaps the biggest shortcoming in such writings are the uncritical use of many Old Testament passages to 
support the continued power of curses over Christians. Such assumptions however are based on a faulty theological understanding, for such curses in the Old Testament actually fall under the YHWH covenant-curse formula instituted between him and Israel in Deuteronomy 28; because of this OT covenantal context, they do not apply to Christians today.

For unbelievers, Scripture however does not indicate any immunity from generational sin or spirits; for God's people, Ex 20:6 is a promise that these sins will cease when they embrace him as their God and he shows mercy to them (Reddin 1999:202).108 Elsewhere in the Old Testament, curses may occur because

of the vows and pledges made to ... deceitful spirits by the kings of Israel, it is likely that the demons laid claim to their sons and daughters, thereby continuing the cycle of bondage ... Similarly, evil spirits will seek to exploit the familial patterns of sinful behavior in the succeeding generation (Arnold 1997:124).

Perhaps a clearer biblical evidence of the idea of intergenerational spirits may be Mark 9:21, where a son is mentioned as having been demonised "from childhood". Here one sees a demon that has afflicted a boy since childhood which tries to induce him towards suicide. However, Clinton Arnold disagrees, stating that

demonization was ... not the result of the boy's own sin or his choice to give his allegiance to false gods. The spirits were passed on to him from some other source, the most likely of which would be his family (1997:119-120).

Because the passage is also silent on the etiology of how this occurs in children and "given the susceptibility of children to the power of suggestion, one should be extremely cautious about proposing a diagnosis of possession in the case of a child" (Page 1995:161).

Curses through generational social and genetic influence

108 As an example, Reddin (1999:206) demonstrates how a generational curse was broken for the Moabites "down to the tenth generation" in Dt 23:3 and Ruth 1:16-17. 
Besides the aspect of generational curses or sins occurring through demons or via the cursing of pagans, one other possible way that it is said to occur is when

children tend to act out many of the same sinful patterns of behavior that their parents engaged in. Thus, when we read Old Testament historical books such as 1 and 2 Kings and 1 and 2 Chronicles, we find the kings of Israel typically followed in the evil steps of their ancestors (Arnold 1997:119-120).

It is this "learned behavior" from the "power of parental example [that] shapes the character of a new human being" as Christians simply cannot be demon-possessed or affected by generational sins or curses (Reddin 1999:198). Sydney Page however notes that "diabolic parentage manifests itself through the failure to love one's brother (1 Jn 3:12)" (1995:204). According to $1 \mathrm{Jn}$ 3:8-10, "sinful behavior reveals that one belongs to the devil, for those who belong to God do not persist in sinning" (ibid.). Thus, if children are exposed to the habitual sins of their parents (such as following other gods), it is highly likely that "the sin of the fathers to the third and fourth generation" (Ex 20:5) will be transmitted (Otis, cited by Wagner 1996:206).

In an encounter with a man born blind in John 9:1-3, we observe that when Jesus' disciples asked whether it was his ancestor's sins that were to blame to for the man's condition, Jesus did not touch on the question of blame but said it was for the glory of God (Jn 9:3). Following Jesus' example and finding no other examples elsewhere in the Bible, we do not find God, his prophets nor apostles concerned about finding the cause of a person's condition, but rather on repentance of $\sin$, deliverance and/or healing. Rather than focusing on the past, Jesus' example focused on the ever present power of God to save, heal and protect in order that God's name would be glorified.

As for the term "familiar spirits", it is "not associated in Scripture with a human family [but] is called 'familiar' because a demonized person has been made 'familiar' with evil spirits who give information that could not be known any other way" (Reddin 1999:203). 
Lastly, generational sins can also be perpetuated through one's descendants genetically. For example, it is scientifically established that diseases or medical conditions such as diabetes, heart attack or alcoholism all have a genetic link to one's parents. Even alcoholism, once considered a social ill, is not found to have a genetic "alcoholic gene". In these ways, it is thus very possible for children to inherit diseases through their parents genetically without attributing it to spiritual causes or to Satan. Though all diseases may plausibly connected to Satan (as seen in Luke's theology of healing and spiritual warfare. See Twelftree 2007 and Collins 2009), the cause of diseases through ancestral genetic transference is ultimately due to the fallen nature of this world.

Curses through bewitched objects or spells

Curses or the possibility of demonization or affliction through objects are said to occur in at least three ways: (1) through an object that has been cursed by a Satanist or pagan (Murphy 1992:443-445), (2) "curses launched at believers by individuals or groups" (Warner 1991:103-104) where "even believers living in holiness are vulnerable to curses" (Warner, cited by Priest et al 1995:23) and (3) food that has been offered to idols.

With regards to the first where "objects can be the medium of demonic power when one has been cursed" (Priest et al 1995:16), this may occur when "engaging in occult practices may invite demons to empower an object, and in this way the demons may become associated with that object (Warner 1991:93). They may include " a tree or hilltop" (Warner 1991:89-90), "artifacts dedicated to enemy gods [that] have demons in them" (Kraft 1989:162), "objects picked up overseas...images or implements used in pagan rituals or dedicated to gods or spirits" (Kraft 1992:112-113) 109, objects because of a death of or prior evil act associated with the object (Kraft (1994b:43; cf. 55-57) or "a building ... 'inhabited by evil spirits' (Kraft 1992:198). Popular writers such as Prince (1995) and Daud Tony also

109 Murphy (1992:447) includes not only "paintings, art, sculptures, images, charms, fetishes, books" but also "some forms of extreme rock." 
subscribe to such beliefs. Priest et al (1995:56) summarises: All of these were "physical objects or substances which were brought into contiguity or contact with persons or objects which were then supernaturally charged".

Kraft also adds that "satanic power can ... reside in ... words [as well as] objects [as] Satan can empower curses and other uses of words" (1989:162). He also believes that

demons [can] enter through cursing ... The power of the curse may be increased through the use of a ritual. In addition, cursed ... objects in a person's possession can provide enemy forces the opportunity to afflict the person, even if not demonized. "Demons seem to be able to 'hook onto' curses that have been leveled at a person's forbears (1992:75-76).

Because of this, Petitpierre (cited by Wimber 1987:117) notes that the "early church also used exorcism on things (water and food), places (especially church sites)". In deliverance ministries then,

it is important to disempower whatever has been empowered with satanic power before attempting to use it. Satanic power can be broken over rituals, buildings, carvings, songs and other custom or artefact a person wants to capture for God's use. In this way, we can capture for Christ cultural forms traditionally used by the enemy. But we shouldn't try to use the forms until the power is broken. Even after the power is broken, there may still be a meaning problem, since people may for centuries have associated rituals and other cultural forms with their allegiance to satanic spirits (Kraft 2002:301).

Priest et al (1995:56) notes that although "Kraft is not wrong ... when he detects certain parallels between the use of such objects in biblical narratives and their use in magic/animism", the

function of contiguity or symbolic association in biblical miracle, however is quite different from its function in magical or animistic thought. In magic and animism, the assumption is that contiguity and symbolic association are themselves the key to power, its transmission, and its effects (ibid:57).

On the flip side, even the dedication of "church buildings...[deal] with God's empowerment" of objects. (Kraft 1995:125). Under this rubric, God also invest/energizes places and things with power, citing the Ark (1 Sam 4-7), 
Jesus' garment (Mt 9:20), Paul's handkerchief and aprons (Ac 19:11-12) as biblical examples (Kraft 1994b:47). Other examples Kraft (ibid.). cites include Aaron stretching his rod over the Nile to turn it to blood (Ex 7:19-20), Moses stretched out his rod over the Red Sea to open a path (Ex 14:16, 21) and struck the rock at Horeb with it to bring forth water (Ex 17:6), Elijah took his cloak, struck the Jordan river with it, and the river parted $(2 \mathrm{Kg}$ $2: 14)$. Elisha cut a stick and threw it in the water to cause the axe head to float (2 $\mathrm{Kg} \mathrm{6:6).} \mathrm{Kraft} \mathrm{(2002:301)} \mathrm{adds} \mathrm{that} \mathrm{if} \mathrm{forms} \mathrm{are} \mathrm{"dedicated} \mathrm{in} \mathrm{the}$ name of Jesus...the elements used in the Lord's Supper can also be dedicated for specific purposes such as blessing and healing and thus empowered".

If God can therefore energise objects and empower them for divine purposes, one must ask whether Satan can do the same and if so, to what degree and how much can Christians be harmed? When we examine Scripture, we see two clear examples where objects are energised. In Exodus 7:11-12, the magicians of Pharaoh are able to give life to a rod that changes into a serpent. In response, God changes Moses' rod likewise. But in a head-tohead show of power encounter, Moses' snake gobbles up the magicians snakes. In Revelation 13:15, Satan's ultimate empowerment upon an object occurs by giving power to the false prophet to animate a statue. The first beast that was worshipped by unbelievers but was wounded is later made into a statue that will come to life by the false prophet. However, we should note that the false prophet can only do so under the power that God gave Satan to deceive the nations at the end times. 110 While the blatant presentation of such objects by Satan's followers before believers (Ex 7:1112, Rev 13:15) shows his direct energizing of objects, Scripture is silent elsewhere on whether the mere possession of foreign objects that are brought into the presence of God's people are similarly empowered.

Three lessons we can learn from these examples are that (1) in both Exodus 7 and Revelation 13, God's people (e.g. Moses and Aaron and believers in consensus of NT scholars (e.g. Osborne 2002) note as power given by God. 
Revelation) are not shown fearing such evil. (2) When Satan arises to oppose or intimidate God's people by energising objects, God not only defends his people but overcomes the enemy, especially in Revelation 19. (3) The power of Satan and evil is limited. They are able to do only so much to the extent that God allows them to.

A third and perhaps the most notable example of objects that are seemingly demonized and/or empowered are idols and food offered to them. This poses constant pastoral and missiological challenges to Asian Christians because it is common for many believers who come from Buddhist or Hindu backgrounds to struggle over whether to eat food sacrificed to idols, particularly during religiously significant events. Some have deep personal struggles over whether eating it will open a door to potential demonisation while others worry about their witness to non-believing family members who may view Christian refusal to eat as dishonouring one's ancestors (Lowe 2001). On this, Ed Murphy (2003:336) opines:

These pagan meals are in fact sacrifices to demons; the worship of demons is involved. One who is already bound to one's Lord and to one's fellow believers through participation at the Lord's table cannot under any circumstances also participate in the worship of demons ... One is not merely eating with friends at pagan temples; one is engaged in idolatry, idolatry that involves the worship of demons.

However, when one studies Paul's view on the matter, he seems to hold two seemingly contradictory statements. In 1 Corinthians 8:4, he says that an "idol is nothing at all in the world" and that "There is no God but one" but in 1 Corinthians 10:20, he states "the sacrifices of pagans are offered to demons, not to God, and I do not want you to be participants with demons".

Arnold explains that to understand Paul here, one must see that the "concept of evil 'powers' behind the worship of pagan deities is present in Paul" as he "believed that a Corinthian believer would actually be joined with demonic 'powers' if he became involved in the table fellowship of pagan deities" (1992:67). This occurred when "an offering brought to them brought 
one under the influence of demonic 'powers' [because] heathen cults were the instruments of the kingdom of Satan" (ibid.).

Thus, on one hand "it seems that Paul believed that the worship of pagan gods put one in contact with maleficent forces and Christians were not immune to the baneful influences of such forces" and that "there is a reality behind the wood or stone of the idol but as evil and unworthy of veneration" (Page 1995:225). On the other hand, an object or status by and of itself is "nothing" because it is lifeless and inanimate. It is when people ascribe reality to an object that demons stand ready to receive their worship through their devotion of such idols or to opportunistically cast fear upon those who believe that objects such as food carry some ontological spiritual reality or power beyond its own material essence (1 Cor 8:7-8).

The problem occurs "when people act wrongly toward such objects based on these meanings which the objects have for them, Satan has power in the lives of those people - just as he always has power in the lives of those whom he successfully deceives, tempts and seduces" (Priest et al 1995:60). It is far better to hold to this view than to state that objects or artefacts "transmit demons," (ibid.) or carry power inherent within itself when no such evidence is found in Scripture. Demons and their energies do not attach themselves permanently to everything that have been dedicated in the occult or through great evil. The evidence of Scripture show that they occur when evil forces intentionally engage in direct conflict towards God's people (e.g. Ex 7 and Rev 12). Elsewhere, it is silent on the matter. They may or may not be associated with the object in some ways (e.g. food sacrificed to idols) but we are not told how in Scripture.

In this sense, Paul's view contrasts with those who assert that "places and things can be polluted by evil and may need to be cleansed before being used by believers" (Page 1995:225 n3).

Another possibly close example is when Israel in the OT brings foreign idols into the land and are warned to not worship them. These idols alone does not constitute a demonic invasion as objects are mere stones and are 
nothing (Psa 115:4-8, Jer 10:14) but should they be worshipped, demonic presence and attachment similar to that of food sacrificed to idols in 1 Corinthians 8 results. Taken together, these verses again mean that pagan religious objects alone are nothing by themselves (Jer 10:3-5, 8-9) but when given an undue attention that raises it to a place of worship, it opens a foothold for demons to enter into the view of the worshipper.

Thus, while there is evidence to say that objects may be charged with powers or animated in certain cases, there is no evidence that close proximity to these objects mean a person is vulnerable to demonisation.

A final example where believers become vulnerable in connection with religious objects is in Acts 19:23-41. There, pagans are inspired to attack Christians when the latter attempt to sever their idol-worship making business. However, no evidence of any direct demonic attack arises even though it occurs in Ephesus, a major centre of idol worship. Beyond this, the New Testament "shows that converts who have been involved in magic should destroy the paraphernalia they have used. This power encounter is an essential rite of separation from old ways and entry into the new life in Christ" (Engelsviken 2000:50). It does not necessarily mean that demons reside in them but destroying them removes a tangible link to the previous pagan beliefs lest they be tempted to return to the old ways.

Curses in early church history

Before concluding our examination on the nature of curses, we must also examine how this phenomenon was understood and dealt with in the early church which "performed the rite of Christian exorcism on all new converts and believers, infant and adult" (Wimber 1987:117). A surface treatment of this phenomenon may argue for the church fathers' belief in the existence of generational sins/curses but a closer examination shows that the church fathers did not link this ritual to a belief in inherited demons.

The ritual of baptismal exorcism was performed by the early church fathers for two reasons (Daunton-Fear 2009): (1) They believed it was vitally 
important as a diagnostic method to detect any lingering demonic attachments that all seekers might have with any evil spirits arising from their pagan background. (2) They considered it a fool-proof method to confirm the spiritual identity and status of new believers as pure followers of Christ. They considered these as real possibilities because during that time, the belief that evil spirits were pervasive among pagans was prevalent. Thus, there was a real concern in the possibility of the demonization of prebelievers and the exposure of their children towards such influences as well. It was thus not surprising that the early Christian church obligated them to undergo baptismal exorcism in the process of being confirmed as believers. For infants and children, the act of baptising and praying for them would offer protection and cleansing from Satan so that any possible traces of demonic attachment were eliminated.

Today, no church practices the rite of baptismal exorcism, whether for infants, children or adults. However, traces of it linger around. For example, in the Anglican church, we find the following formula for infants and younger children (to be read by the parents and godparents when the candidates are unable to answer for themselves):

Parents and Godparents: I present [Name] to receive the Sacrament of Baptism. When all have been presented the Celebrant asks the parents and godparents:

Will you be responsible for seeing that the child you present is brought up in the Christian faith and life?

Parents and Godparents: I will, with God's help.

Celebrant: Will you by your prayers and witness help this child to grow into the full stature of Christ?

Parents and Godparents: I will, with God's help.

Then the Celebrant asks the following questions of the candidates who can speak for themselves, and of the parents and godparents who speak on behalf of the infants and younger children

Question: Do you renounce Satan and all the spiritual forces of wickedness that rebel against

God?

Answer: I renounce them.

Question: Do you renounce the evil powers of this world which corrupt and destroy the creatures of God?

Answer: I renounce them.

We should note that this particular formula or any variation that includes the renunciation of the Satan and his works is however standard only in the 
Anglican, Catholic and Orthodox tradition but missing in most other Protestant traditions. Here we should ask: if the early Christian church took the continued possible presence of demonic attachment seriously when confirming not only infants and children but also adult new believers in Christ, should not other churches that perform baptism (but do not include such formulas) consider this? At present, only formulas of blessing and dedication to the Lord are mainly said in infant baptisms or child dedication services. What is often missing is the prayer of protection from evil in the ritual and renunciation of Satan and his works.111

Timothy Warner (1991:108) remarks that "in the Early Church, this would have been handled as part of the conversion-baptism process. It is to our detriment that we have abandoned the practice of having every baptismal candidate renounce the devil and all of his works". Outside the church, in the context of the mission field, the practice of infant baptism or dedications is to be commended to an even greater degree. Engelsviken (2001:34) adds that in some cases overseas where children had been dedicated to foreign gods or in witchcraft, the risks of demonization are higher, thus (infant) baptismal exorcism or a clear renunciation of Satan and his works by adults becomes more important. Finally, evangelicals should ask themselves, why do the words in the sinner's prayer for salvation lack a renunciation of Satan as well?

A biblically integrated view of curses and salvation

We have seen that with regards to the occurrence of curses in Scripture, God is the originator of the curse in Gen 3:14 when the serpent's sin is discovered and punished. Following this, two succeeding curses are then pronounced upon the woman and man (Gen 3:16-19). Reddin states: "God has indeed cursed sin and sinners (Matt 25:41) The original curse of

111 Craig Ott (private conversation, February 2011) from Trinity Evangelical Divinity School relates that there is a practice among some Christians in Germany to query some aspects of their background whether they have been previously involved in the occult and so on as part of their discipleship process and if so, they are asked if they have confidence in Christ. If not, they are asked to renounced these past involvements and to place their trust in Christ. 
Genesis 3 affects every human being and all of creation (Rom 8:19-23) ... No one can break a curse placed by God - except God himself!"112 This curse - that of physical death to all, childbearing pain upon the woman and thorns and thistles in the environment are all part of God's curse due to sin in the world. These curses continue to affect all people until they die. No magical words or special charismatic prayers can expel nor neutralise them.

It is in this sense that one can all agree that any kind curses - whether they are generational sins/curses or curses from God, are ontologically real as the Bible reveals them to be so. In the first curse, as fallen human beings, we all inherit this as Adam's descendants. As for the covenant curses, they only apply to Israel, with whom God cut the original covenant with. Beyond these two instances, nowhere in Scripture do we find any evidence that pagans who curse God's people are efficacious. Even when "Balaam tried to curse God's people, he could not (Num 23:8, 19-20)" (Reddin 1989:200). Thus, "no one can bless whom God has cursed, and no one curse whom God has blessed" (ibid.). In the New Testament, Christ breaks the curse of sin by taking on the curse upon Himself on the tree (Gal 3:13). As a result of Christ's death on that tree which was the cross, God broke the curse of sin. Peter could therefore say that "by his stripes we are healed (1 Pet 2:24). Finally, Paul writes that when Christians are cursed and persecuted, instead of binding the strongman or asking God to repel any curses spoken against Christians or for him to remove human opposition, "when we are cursed, we bless; when we are persecuted, we endure it” (1 Cor 4:12). For Paul, the power of a curse was to be counteracted by the power of blessing.

Because there is no explicit mention of demonisation as a result of curses on believers, to posit such beliefs is to impose an animistic assumption on the lives of Christians who have been saved by the cross of Christ and who has broken not only the curse of sin but will redeem us from the curse of death in the resurrection as well.

112 Interestingly, a brief overview of curses in Scripture show that it is God who is most often shown cursing, which effects realities in the spirit and natural world (e.g. Gen 3:14, 17; 5:29; 27:29; Jer 17:5, etc.). 
A holistic view of sin and curse will acknowledge that they are complex and its presence and effects may be multi-causal. Because of this, it is more accurate to state that the influence of $\sin$ in the world and in human fallenness still continue as a result of the curse in Genesis 3. The curse of sin also affects Christians but in sometimes indirect ways (see Diagram 1 below).

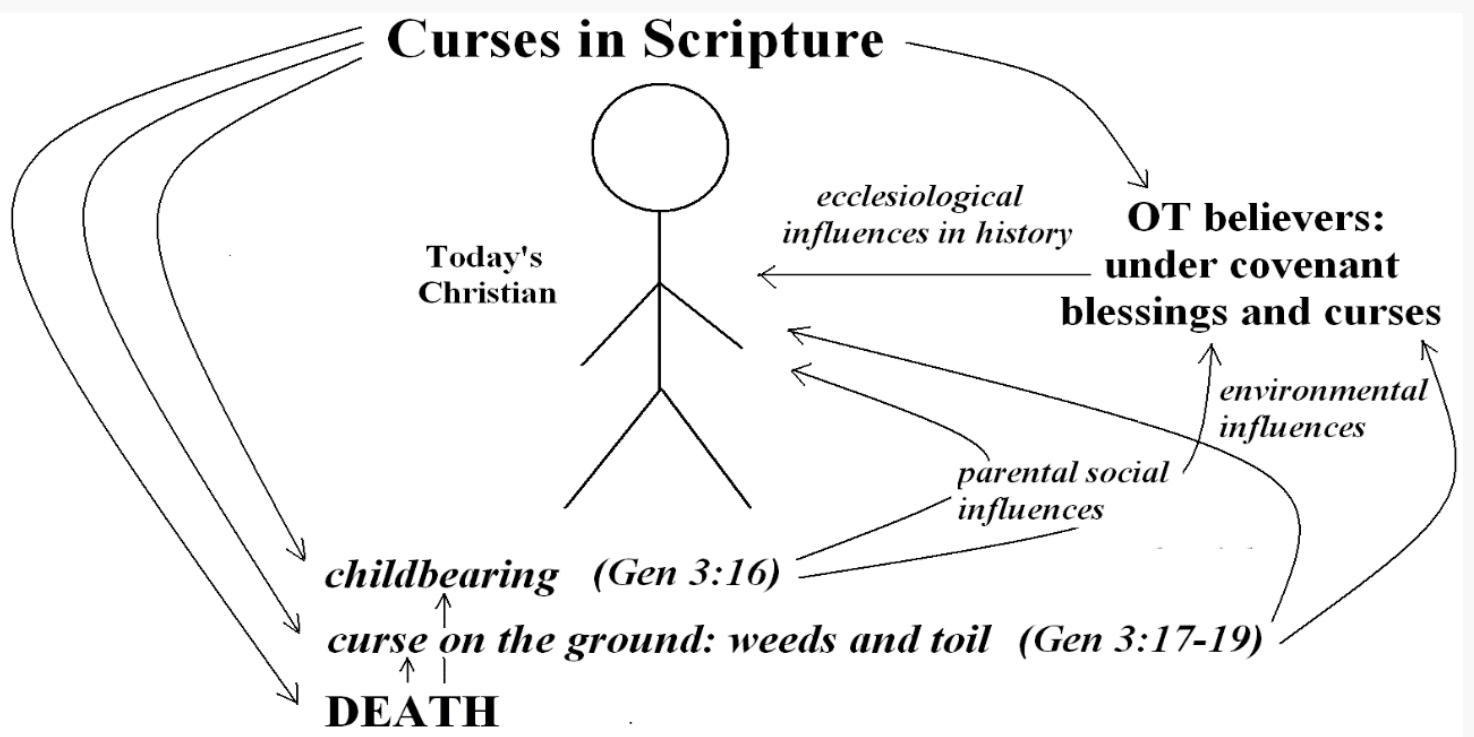

The generational sin/curse that began with Adam afflicts not only individuals but their relations with other people as well as to the work we do and to the earth. Because of this multidimensional aspect of sin, a gospel that truly preaches the Good News of Jesus Christ will also account for how God's salvation plan not only removes the curse of sin upon us and our salvation as saved individuals, but also transforms our relationship with people, and redeems the environment that sin has cursed in all its totality.

\section{Conclusion}

Not all curses are efficacious nor lead to demonization of Christians. This paper has endeavoured to show that it is only curses originating from God are efficacious towards everyone, including Christians. However, those originating from pagans or evil forces directed towards his people are not 
always so. The uncritical use of Old Testament passages and simplistic exegesis of bible passages to assert the continued presence of generational sins or curses upon Christians today shakes the confidence of ordinary Christians who absorb such teachings.

The reality for Christians is that God offers believers total and allencompassing protection and healing from any form of curses hurled towards them by pagans. When Christians trust in the power of Christ and embrace the cross, all powers of hell and evil are defeated. Col 2:15 tells us that Christ "having disarmed the powers and authorities ... made a public spectacle of them, triumphing over them by the cross".

Christians also "need not pursue an etiology of demonisation as part of its cure for [in] the bible, the cure is more important than the cause of demonisation. Instead, we need to practice God's presence more than Satan's presence" (Cheong 2012:9). When Christians spend more time researching, reading and thinking of the causes and strategies of the enemy rather than meditating on Christ, living in confidence upon his redemptive work accomplished at the cross, and ministering in the power of the Holy Spirit, we give more power and though to Satan than necessary.

Eventually if Christians begin accommodating and accepting all, if not some pagan beliefs concerning the efficacy of curses, they will effect some aspects of reality. At minimum, it will generate personal emotional and psychological views that make them vulnerable psychologically and spiritually. Believers who have been redeemed by the blood of Christ will live in continued fear of any generational sin or fear of inadvertently touching a cursed object. It will not only weaken one's faith and sufficiency in the power of God who breaks all curses and protects believers from evil, it exposed Christians to a life of uncertainty.

At the same time, Satan also attempts "to steal and kill and destroy" (Jn 10:10) as well as to masquerade or counterfeit the true (2 Cor 11:14). Because he is a created being and not the original creator, he can only take that which is originally created by God to twist and use it for his own ends. 
If God possesses power to energise objects and to use them to bless or curse others, Satan can do the same but for evil means. However, they are mere shadows and counterfeits to the power and efficacy of the real powers of God. According to Kraft, "there is a true set of principles and practices that God himself has put in the universe on the basis of which humans are to relate to the spirit world ... the ways in which the animists misanalyze are not so much due to a misunderstanding of the principles as to their application of them" (1995:98) "The major differences, then, in the operation of spiritual principles lie in the source of the power and the way they are used, not in the principles themselves" (ibid.:105).

Even so, it is not accurate to say that God and Satan work on the "same principles" and that there is a one-to-one correspondence or mirror image in the way that because God energizes objects and curses things, so does Satan (e.g. Kraft 1995:98, 105). This study has however endeavoured to show that in some cases, it is possible a curse may not necessarily be the direct cause of illness towards a Christian. Satan may take advantage of the utterance of a curse to demonise the believer directly and inflict illness or misfortune. Such causes of illness or afflictions are attested biblically (e.g. Luke, Mark etc.) but with regards to curses, we find no such direct correlation nor examples in Scripture affecting believers.

This is also not to say that Christians should walk unaware of Satan and his evil schemes. Scripture provides believers with sufficient information and warning to be alert enough to sufficiently understand and act against Satan such as "(John 10), " "flee from the devil" (Jas 4: ), (1 Pet 5:8) and so on. But again, beyond such clear warnings and instructions, nowhere are we commanded to consult demon dictionaries in order to "know your enemy [and] defeat him!" (Daniels 2013).

Finally, even when there are testimonies by people and experiences of missionaries on the phenomenon of curses that seem to validate the power of pagan curses or cursed objects upon believers, we must carefully weigh such testimonies against the full weight of Scripture without also dismissing 
such experiences (Engelsviken 2001). Without necessarily emphasizing whether cursing are efficacious, missionaries and even the ordinary Christian should at minimum pray for God's blessing and protection from the evil one (Mt 6:13). If Jesus thought that protection from evil was vitally important that he included it as one of the key elements for his disciples to pray daily, we should we do any less? 113

\section{References}

Anderson, Allan. 2004. An introduction to Pentecostalism. New York: Cambridge University Press. . 2013. To the ends of the earth: Pentecostalism and the transformation of world Christianity. New York: Oxford University Press.

Arnold, Clinton E. 1992. Ephesians: Power and magic. Grand Rapids, MI: Baker. 1997. Three crucial questions about spiritual warfare. Grand Rapids, MI: Baker.

Brown, Rebecca and Daniel Yoder. 1995. Kutuk yang belum dipatahkan: Sumber masalah tersembunyi dari hidup anda. Jakarta: Light Publishing.

Cheong, Weng Kit. 2013. A settled debate? Reassessing spiritual warfare past and present for the

$21^{\text {st }}$ century. EMS Occasional Bulletin. 26, no.2 (Spring): 1-11.

Collins, James M. 2009. Exorcism and deliverance ministry in the twentieth century. Milton Keynes: Paternoster.

Dallen, J., J. Gratsch and L.J. Elmer. 2003. Exorcism. In The New Catholic Encylopedia, $2^{\text {nd }}$ edition, 551-553. New York: Thomas Gale.

Daunton-Fear, Andrew. 2009. Healing in the early church. Colorado Springs: Paternoster

Dawson, John. 1989. Taking our cities for God. Lake Mary, FL: Creation House.

Daniels, Kinberly. 2013. The Demon Dictionary Volume One: Know Your Enemy. Learn His Strategies. Defeat Him! Lake Mary, FL: Charisma House.

Dickason, C. Fredrick. 1987. Demon possession and the Christian. Chicago: Moody.

113 Moreau (1997:163) adds that we should pray for protection in our sleep lest we experience nightmares as well as part of God's protection over us and our children. 
Engelsviken, Tormod, ed. 2001. Spiritual conflict in today's mission: A report from the Consultation on "Deliver Us from Evil, August 2000, Nairobi, Kenya. Nairobi: Association of Evangelicals of Africa.

Kraft, Charles H. 1989. Christianity with power. Ann Arbor, MI: Vine Books. 1992. Defeating dark angels. Ann Arbor, MI: Servant.

1993. Deep wounds, deep healing. Ann Arbor, MI: Servant. 1994. Spiritual power: Principles and observations. In Behind enemy lines, ed. Charles H. Kraft. 31-62. Ann Arbor, MI: Servant. 1995 "Christian animism" or God-given authority? In Spiritual power and missions, ed. Edward Rommen, 88-137. Pasadena, CA: William Carey.

2002. Contemporary trends in the treatment of spiritual conflict. In Deliver us from evil: An uneasy frontier in Christian mission, eds. A. Scott Moreau, et al. 177-202. Monrovia, CA: World Vision International.

Lowe, Chuck. 2001. Honoring God and family: A Christian response to idol food in Chinese popular religions. Bangalore: Theological Book Trust.

Moreau, A. Scott. 1997. Broadening the issues: Historiography, advocacy and hermeneutics. In The Holy Spirit and Mission Dynamics, ed. C. Douglas McConnell. 121-135. Pasadena, CA: William Carey. . 1997. Essentials of spiritual warfare. Wheaton: Harold Shaw.

Murphy, Ed. 2003. The handbook for spiritual warfare. Nashville, TN: Thomas Nelson.

Osborne, Grant. 2002. Revelation. (Baker Exegetical Commentary on the New Testament). Grand Rapids, MI: Baker Academic.

Page, Sydney H. T. 1995. Powers of Evil: A biblical study of Satan and demons. Grand Rapids, MI: Baker.

Parsons, Martin. 2007. Binding the strong man: The flaw of the excluded middle. In Angels and demons: Perspectives and practice in diverse religious traditions, eds. Peter G. Riddell and Beverly Smith Riddell. 106-125. Nottingham: Apollos.

Powlison, David. 1995. Power encounters. Grand Rapids, MI: Baker.

Priest, Robert J., Thomas Campbell, and Bradford A. Mullen. 1995. Missiological syncretism: The new animistic paradigm. In Spiritual power and missions, ed. Edward Rommen, 9-87. Pasadena, CA: William Carey.

Priest, Robert J. 1997. Spiritual warfare, epistemology, and the missiological community. In The Holy Spirit and Mission Dynamics, ed. C. Douglas McConnell. 136-146. Pasadena, CA: William Carey.

Prince, Derek. 2008. Tinggalkan kutuk, terimalah berkat. Indonesia: Derek Prince Ministries. 
Reddin, Opal. 1989. Generation curses, strongholds, binding and loosing, deliverance ministry. In Power encounter: A Pentecostal perspective, ed. Opal L. Reddin. 198-239. Springfield: Central Bible College.

Twelftree, Graham. 2007. In the name of Jesus: Exorcism among early Christians. Grand Rapids, MI: Baker Academic.

Wagner, C. Peter. 1996. Confronting the powers. Ventura, CA: Regal.

Warner, Timothy. 1991. Spiritual warfare. Wheaton: Crossway.

Wimber, John. 1987. Power healing. San Francisco: Harper and Row.

\section{Biodata of author:}

Dr Cheong Weng Kit serves at Sabah Theological Seminary in Malaysia as a fulltime lecturer in missiology and intercultural studies. He has a ThM and a $\mathrm{PhD}$ in Intercultural Studies. He researches and writes on Asian Pentecostalism, work, money and mission, globalisation and world religions. He has edited three books and published over 30 articles on the Trinity, Pentecostalism, mission and world religions, contextual theology, globalisation and urban missiology.

\section{Contact information:}

Dr Cheong Weng Kit

c/o Sabah Theological Seminary

26 Jalan Pinggir, off Jalan Istana

88400 Kota Kinabalu

Sabah

MALAYSIA.

Email: wkcheong@stssabah.org 